\title{
Decline of the Jakarta Bay molluscan fauna linked to human impact
}

\author{
Sancia E.T. van der Meij ${ }^{\mathrm{a}, *}$, Robert G. Moolenbeek ${ }^{\mathrm{b}}$, Bert W. Hoeksema ${ }^{\mathrm{a}}$ \\ a National Museum of Natural History Naturalis, P.O. Box 9517, 2300 RA Leiden, The Netherlands \\ ${ }^{\mathrm{b}}$ Zoological Museum Amsterdam (ZMA), Mauritskade 57, 1092 AD Amsterdam, The Netherlands
}

\section{A R T I C L E I N F O}

\section{Keywords:}

Java

Kepulauan Seribu

Reef degradation

Anthropogenic influence

Scientific collections

Mollusca

\begin{abstract}
A B S T R A C T
In 1937/38 representative mollusc collections were made in Jakarta Bay (West Java, Indonesia). New data from here and the adjacent offshore Thousand Islands archipelago (Kepulauan Seribu) became available in 2005. Although collecting efforts and sampling methods differed, a comparison of the molluscan fauna of Jakarta Bay between 1937/38 and 2005 reveals a distinct deterioration. From 1937 to 2005, Jakarta Bay received increasing amounts of sewage from the greater Jakarta area, as well as increased sediment input from the deforested West Java hinterland. Predatory gastropods and numerous mollusc species associated with carbonate (reef) substrate have vanished from Jakarta Bay, among which many edible species. (c) 2009 Elsevier Ltd. All rights reserved.
\end{abstract}

\section{Introduction}

Social and economic development in tropical regions inevitably involves accelerated urbanization of coastal areas that impact nearby coral reefs (Ginsburg, 1993). The majority of the Indonesian population lives on Java and therefore the coastal resources are under considerable human pressure. Over the years, the waters of Jakarta Bay show an increase in eutrophication and sedimentation levels, which has had a documented impact on marine communities (Brown, 1986; Verstappen, 1988; Tomascik et al., 1993; Marques et al., 1997; Renema, 2008). Coral reefs became degraded as a result of increased sedimentation, nutrient loading, and chemical contamination (Rees et al., 1999; Williams et al., 2000). Such chronic, continuing disturbances have a negative impact on nearby coral reefs. Little recovery has been documented after these types of disturbances (Connell, 1997).

Long-term faunal comparisons (decades) in a single marine area are scarce, although some work has been carried out on coral reefs in Jamaica, Barbados, Hawaii, and Australia (Bell and Tomascik, 1993; Hunter and Evans, 1993; Hughes and Connell, 1999). Studies in the Indo-West Pacific, and particularly studies including changes in molluscan faunas in Indonesia, are limited (Poorten, 2007).

This study provides insight into faunal composition changes in the molluscan fauna of Jakarta Bay and adjacent reefs of the Thousand Islands archipelago (Fig. 1). In the early 1900s, several marine biota studies were conducted on the reefs in Jakarta Bay (Umbgrove and Verwey, 1929; Verwey, 1931). In particular molluscs were collected by various researchers in 1937/38, and deposited in the Zoological Museum Amsterdam (ZMA) and the National Museum of Natural History (Naturalis). During a 2005 research expe-

\footnotetext{
* Corresponding author. Tel.: +31 715687 631; fax: +31 715687666.

E-mail address: MeijS@naturalis.nl (S.E.T. van der Meij).
}

dition molluscs were again collected on the same localities as in $1937 / 38$, thus enabling a comparison of the Jakarta Bay molluscan fauna over long temporal periods.

\section{Material and methods}

\subsection{Research area}

All research was conducted in Jakarta Bay and the adjacent reef complex of the Thousand Islands archipelago. This reef complex is located NNW of Jakarta, which houses over 12 million inhabitants in a $460-\mathrm{km}^{2}$ area. It is one of the largest urban areas located in close vicinity to a coral reef complex. Jakarta Bay is bordered by two capes, Tanjung Pasir to the west and Tanjung Karawang to the east. Three major rivers discharge fresh water and silt into Jakarta's reef area: the Cisadane, most westward and just outside the bay, the Angke, most southward inside the bay, and the Citarum, with a large river delta in the easternmost cape (Verstappen, 1953; Moll and Suharsono, 1986). The Citarum river carries large quantities of silt to the east side of the bay, confining the presence of coral reefs to its western part only (Umbgrove and Verwey, 1929), which also demonstrates the restricting effect of siltation in general. In addition, the bay receives highly polluted water from the rivers that drain metropolitan Jakarta. Jakarta Bay is less than $30 \mathrm{~m}$ deep, with a bottom composition of terrestrial mud, coral sand, rubble and coralline algae (Ongkosongo, 1989). The Thousand Islands are separated from the bay area by a channel with a depth of about $100 \mathrm{~m}$ connected to the Sunda Strait (Umbgrove, 1929).

The Kepulauan Seribu Marine National Park, declared a National Reserve in 1982, is known for its maritime tourism (Uneputty and Evans, 1997). Together with the islands within Jakarta Bay, the archipelago forms a chain of islands stretching some $80 \mathrm{~km}$ in a 


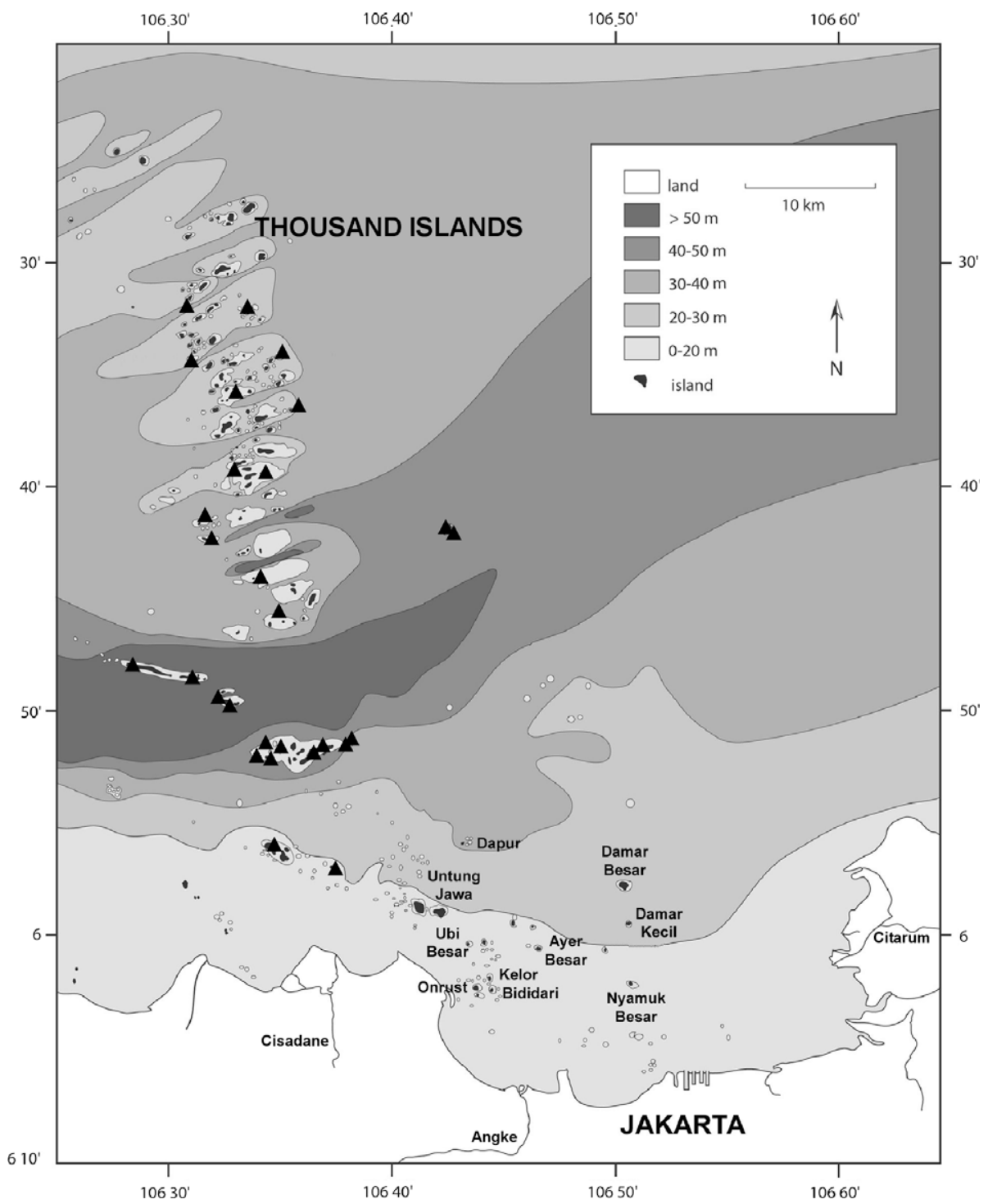

Fig. 1. Map of research area, triangles indicate the 2005 sampling localities in the Thousand Islands archipelago.

NNW offshore direction $\left(5^{\circ} 47^{\prime}-5^{\circ} 24^{\prime}\right.$ S) perpendicularly to the coast line and $30 \mathrm{~km}$ from west to east $\left(106^{\circ} 23^{\prime}-106^{\circ} 37^{\prime} \mathrm{E}\right)$. In all, the reef complex consists of over 108 small ( $<10 \mathrm{ha}$ ) and lowlying (<3 m asl) coral cays (Brown, 1986).

\subsection{Data collection}

The long-term presence of research facilities and activities in the region contributed to the present availability of prior scientific collections. These collections allow for comparison of data collected in 1937/38 and 2005. The collection gap covers about 70 years, and differences in collection methods are therefore unavoidable. In 1937/38, molluscs were collected primarily by beach combing, or by wading during low tide. Additionally, some material was collected through dredging. In 2005, 38 patch reefs throughout the Kepulauan Seribu reef complex (including Jakarta Bay) were assessed (Fig. 1). The reefs were sampled in an environmental south-to-north, near-shore to offshore gradient, potentially representing decreasing effects of urbanization and river discharge. At each locality one hour was spent on SCUBA and additional beach material was collected at seven localities. Many beaches are now cleaned daily by resort owners, thus limiting representative shell collecting. All specimens from this study were deposited in the collections of the Zoological Museum in Bogor (presently at Cibinong), ZMA, and Naturalis. By comparing the 2005 data of Jakarta Bay and the Thousand Islands, a possible discriminating effect of sampling effort was ignored in order to determine molluscan species richness in Jakarta Bay.

Six major molluscan families are included in this study: the gastropod families Cypraeidae, Conidae, and Nassariidae; and the bivalve families Cardiidae, Pectinidae, and Veneridae. These families were selected on their accessibility in the collections and the availability of taxonomic experts for identification. The three bivalve and three gastropod families represent different (aut-)ecological signatures. Venerid bivalves are infaunal filter feeders. Cardiid bivalves include epifaunal, infaunal as well as semi-infaunal taxa, most of which are filter feeders but some of which might be deposit feeders. Pectinids are epifaunal to semi-infaunal filter feeding taxa. Cypraeids are herbivorous grazers, while nassariid and conid snails are vagile carnivores and/or scavengers. Conid and cypraeid snails are associated with (semi-)consolidated sea bottoms, including reef rubble or coral stands.

Results are presented for the entire Jakarta Bay, and for the individual islands in the bay. The 1937/38 data for the Cardiidae and Pectinidae are not separated per island and are therefore solely included in the analysis of the entire Jakarta Bay. Data collected in 
2005 from the adjacent Thousand Islands are added for comparison with the diversity changes in Jakarta Bay between the 1937/38 and 2005.

\section{Results}

Species numbers for all six molluscan families in the bay area have declined (Figs. 2 and 3). The changes in species richness of four families were documented for nine islands in Jakarta Bay (Fig. 2). The decreasing species richness trend of the islands is similar to the overall trend for the entire bay area.

Most species found in Jakarta Bay in 2005 are venerids. At Kelor reef six species of Conidae were collected, while five species of cypraeids and nassariids were found at Damar Besar reef (Table 2). Nyamuk Besar Isl. has disappeared due to coral mining and its reef fauna is in decline (DeVantier et al., 1998). This island was once considered among the most beautiful islands in a 1950 study (Verstappen, 1988). The sea bottom at Ubi Besar reef consists mainly of rubble, while the reefs of Damar Besar, Untung Jawa and Dapur are sand. In 2005, Damar Besar reef consisted of dead coral cover and rubble. The decline in species numbers of Ayer Besar is mainly explained by the loss of cypraeid species; in 1937/38 nine species were found compared to zero in 2005. As shown on the map (Fig. 1), the reefs of Kelor and Bidadari are located next to each other, and both harbour about the same number of species.

\subsection{Composition change 1937/38 - 2005}

Considering the total number of species, the $1937 / 38$ collection is far richer than the one of 2005. Based on the before mentioned six families, Jakarta Bay housed 171 species of molluscs in 1937/ 38, compared to 58 species in 2005 (Fig. 3). By comparison, the
Table 1

Genera only collected in $1937 / 38$ or 2005 .

\begin{tabular}{|c|c|c|c|}
\hline Family & Genus & Only in $1937 / 38$ & Only in 2005 \\
\hline \multirow[t]{6}{*}{ Cardiidae } & Corculum & $\mathrm{x}$ & \\
\hline & Laevicardium & & $\mathrm{x}$ \\
\hline & Lunulicardia & $\mathrm{x}$ & \\
\hline & Lyrocardium & & $\mathrm{x}$ \\
\hline & Maoricardium & $\mathrm{x}$ & \\
\hline & Vepricardium & $\mathrm{x}$ & \\
\hline \multirow[t]{3}{*}{ Cypraeidae } & Cribrarula & & $\mathrm{x}$ \\
\hline & Notadusta & & $\mathrm{x}$ \\
\hline & Talparia & & $\mathrm{x}$ \\
\hline Nassariidae & Hebra & $\mathrm{x}$ & \\
\hline \multirow[t]{8}{*}{ Pectinidae } & Amusium & $\mathrm{x}$ & \\
\hline & Bractechlamys & $\mathrm{x}$ & \\
\hline & Complicachlamys & & $\mathrm{x}$ \\
\hline & Coralichlamys & & $\mathrm{x}$ \\
\hline & Minnivola & $\mathrm{x}$ & \\
\hline & Pedum & & $\mathrm{x}$ \\
\hline & Serratovola & $\mathrm{x}$ & \\
\hline & Volachlamys & $\mathrm{x}$ & \\
\hline \multirow[t]{7}{*}{ Veneridae } & Anomalocardia & $\mathrm{x}$ & \\
\hline & Clementia & $\mathrm{x}$ & \\
\hline & Meretrix & $\mathrm{x}$ & \\
\hline & Paphia & $\mathrm{x}$ & \\
\hline & Placamen & $\mathrm{x}$ & \\
\hline & Samarangia & & $\mathrm{x}$ \\
\hline & Sunetta & $\mathrm{x}$ & \\
\hline
\end{tabular}

2005 Kepulauan Seribu mollusc fauna contained 137 species for the six studied families. A complete species list is provided (Table 2).

About 95 species appear to have been lost between 1937/38 and 2005. Seventeen species not found in 1937/38 were observed in Jakarta Bay in the 2005 campaign (Table 2). Also a noted change in generic composition was found between the 1937/38 and 2005

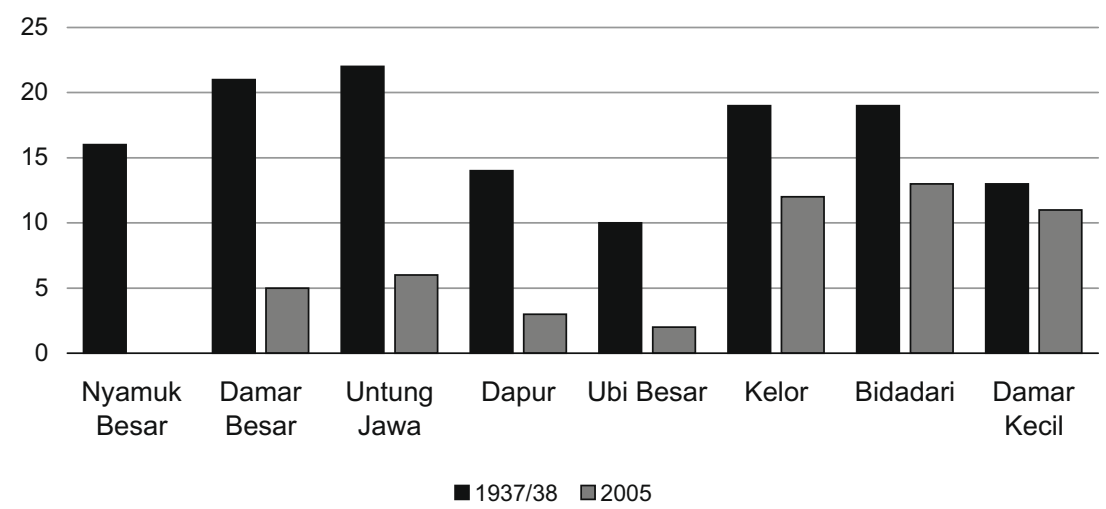

Fig. 2. Number of molluscan species (Conidae, Cypraeidae, Nassariidae, Veneridae) collected around the islands in Jakarta Bay, $1937 / 38-2005$.

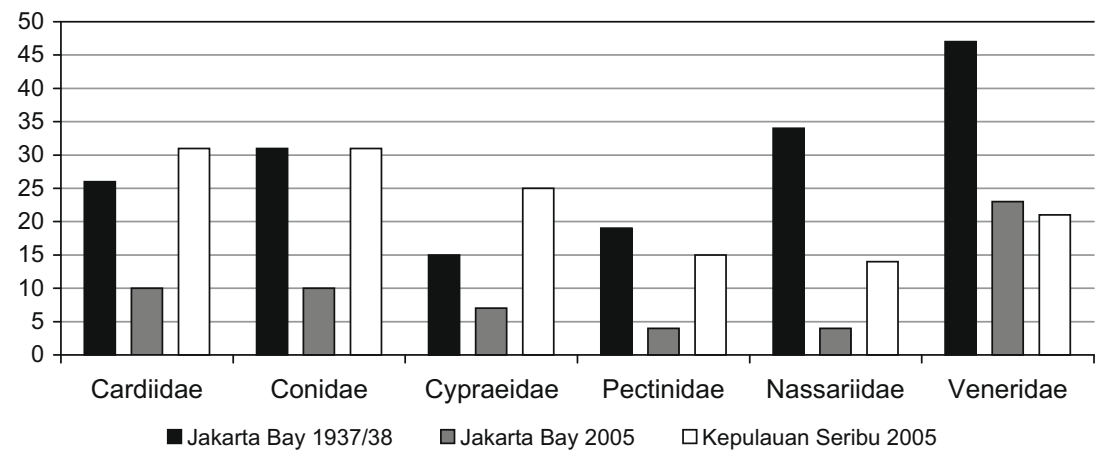

Fig. 3. Number of collected species per family in Jakarta Bay (1937/38 and 2005) and Kepulauan Seribu 2005. 
Table 2

Species list.

\begin{tabular}{llll}
\hline & $1937 / 38$ & 2005 & \\
\cline { 3 - 4 } & Jakarta & Jakarta & Kep. \\
Bay & Bay & Seribu
\end{tabular}

Cardiidae

Acrosterigma impolitum (Sowerby, 1833)

A. maculosum (Wood, 1815)

A. punctolineatum Healy \& Lamprell, 1992

$\mathrm{x}$

A. simplex (Spengler, 1799)

A. transcendens (Melvill \& Standen, 1899)

Afrocardium exochum (Melvill \& Standen, 1906)

A. richardi (Audouin, 1826)

Corculum cardissa (Linnaeus, 1758)

Ctenocardia fornicatum (Sowerby, 1840)

C. gustavi Vidal \& Kirkendale, 2007

C. virgo (Reeve, 1845)

C. spec.

Fragum fragum (Linnaeus, 1758)

F. scruposum (Deshayes, 1855)

F. sueziense (Issel, 1869)

F. unedo (Linnaeus, 1758)

Frigidocardium iris Huber \& ter Poorten, 2007

F. torresi (Smith, 1885)

F. spec. nov. ter Poorten \& Poutiers, MS

Fulvia aperta (Bruguière, 1789)

F. australis (Sowerby, 1841)

F. hungerfordi (Sowerby, 1901)

F. imperfecta Vidal \& Kirkendale, 2007

F. laevigata (Linnaeus, 1758)

F. scalata Vidal, 1994

F. undatopicta (Pilsbry, 1904)

Laevicardium attenuatum (Sowerby, 1841)

L. biradiatum (Bruguière, 1789)

L. lobulatum (Deshayes, 1855)

Lunulicardia retusa (Linnaeus, 1767)

Lyrocardium aurantiacum (Adams \& Reeve, 1850)

Maoricardium setosum (Redfield, 1846)

Microfragum subfestivum Vidal \& Kirkendale, 2007

Vasticardium angulatum (Lamarck, 1819)

V. flavum subrugosum (Sowerby, 1840)

V. luteomarginatum (Voskuil \& Onverwagt, 1991)

V. orbita philippinense (Hedley, 1899)

V. papuanum Vidal, 1996

V. pectiniforme (Von Born, 1780)

V. rubicundum kengaluorum Voskuil \& Onverwagt, 1993

Vepricardium asiaticum (Bruguière, 1789)

V. coronatum (Schröter, 1786)

V. multispinosum (Sowerby, 1838)

$V$. sinense (Sowerby, 1838)

Conidae

Conus achatinus Hwass, 1792

C. arenatus Hwass, 1792

C. artoptus Sowerby, 1833

C. aulicus Linnaeus, 1758

C. balteatus Sowerby, 1833

C. biliosus (Röding, 1798)

C. canonicus Hwass, 1792

C. capitaneus Linnaeus, 1758

C. caracteristicus Fischer, 1807

C. catus Hwass, 1792

C. concors Sowerby, 1833

C. coronatus Gmelin, 1791

C. cylindraceus Broderip \& Sowerby, 1830

C. distans Hwass, 1792

C. ebraeus Linnaeus, 1758

C. eburneus Hwass, 1792

C. emaciatus Reeve, 1849

C. eximius Reeve, 1849

C. genuanus Linnaeus, 1758

C. geographus Linnaeus, 1758

C. glans Hwass, 1792

C. litoglyphus Hwass, 1792

C. litteratus Linnaeus, 1758

C. lividus Hwass, 1792

C. magnificus Reeve, 1843
Table 2 (continued)

\begin{tabular}{l}
\hline \\
\hline C. magus Linnaeus, 1758 \\
C. marmoreus Linnaeus, 1758 \\
C. miles Linnaeus, 1758 \\
C. miliaris Hwass, 1792 \\
C. musicus Hwass, 1792 \\
C. musicus fa. Hwass, 1792 \\
C. mustelinus Hwass, 1792 \\
C. mussatella Linnaeus, 1758 \\
C. obscurus Sowerby, 1833 \\
C. omaria Hwass, 1792 \\
C. parvatus Walls, 1979
\end{tabular}

\begin{tabular}{|c|c|c|}
\hline $1937 / 38$ & 2005 & \\
\hline $\begin{array}{l}\text { Jakarta } \\
\text { Bay }\end{array}$ & $\begin{array}{l}\text { Jakarta } \\
\text { Bay }\end{array}$ & $\begin{array}{l}\text { Kel } \\
\text { Ser }\end{array}$ \\
\hline $\mathrm{x}$ & & $\mathrm{x}$ \\
\hline $\mathrm{x}$ & & $\mathrm{x}$ \\
\hline $\mathrm{x}$ & & \\
\hline $\mathrm{x}$ & & $\begin{array}{l}x \\
x\end{array}$ \\
\hline $\mathrm{x}$ & & $\mathrm{x}$ \\
\hline $\mathrm{x}$ & & $\mathrm{x}$ \\
\hline $\mathrm{X}$ & & \\
\hline $\mathrm{X}$ & & \\
\hline
\end{tabular}

$C$ parvatus Walls

C. planorbis Von Born, 1778

C. radiatus Gmelin, 1791

C. rattus Hwass, 1792

C. scabriusculus Dillwyn, 1817

C. stercusmuscarum Linnaeus, 1758

C. stramineus Lamarck, 1810

C. striatellus Link, 1807

C. striatus Linnaeus, 1758

C. striolatus Kiener, 1845

C. telatus Reeve, 1848

C. tenuistriatus Sowerby, 1858

C. terebra Von Born, 1778

C. tessulatus Von Born, 1778

C. textile Linnaeus, 1758

C. tulipa Linnaeus, 1758

C. varius Linnaeus, 1758

C. vexillum Gmelin, 1791

C. virgo Linnaeus, 1758

C. zebra Lamarck, 1810

C. spec. 1

C. spec. 2

Cypraeidae

Bistolida kieneri (Hidalgo, 1906)

B. ursellus (Gmelin, 1791)

Blasicrura interrupta (Gray, 1824)

B. quadrimaculata (Gray, 1824)

Cribrarula cribraria (Linnaeus, 1758)

Erosaria annulus (Linnaeus, 1758)

E. caputserpentis (Linnaeus, 1758)

E. erosa (Linnaeus, 1758)

E. labrolineata (Gaskoin, 1849)

E. moneta (Linnaeus, 1758)

Erronea cylindrica (Von Born, 1778)

E. errones (Linnaeus, 1758)

E ovum (Gmelin, 1791)

E. walkeri (Sowerby, 1832)

Luria isabella (Linnaeus, 1758)

Lyncina carneola (Linnaeus, 1758)

L. leviathan (Schilder \& Schilder, 1937)

L. lynx (Linnaeus, 1758)

Notadusta punctata (Linnaeus, 1771)

Palmadusta asellus (Linnaeus, 1758)

P. saulae (Gaskoin, 1843)

P. ziczac (Linnaeus, 1758)

Purpuradusta gracilis (Gaskoin, 1849)

P. minoridens (Melvill, 1901)

Pustularia bistrinotata Schilder \& Schilder, 1937

P. cicercula (Linnaeus, 1758)

Staphylaea nucleus (Linnaeus, 1758)

S. staphylaea (Linnaeus, 1758)

Talparia talpa (Linnaeus, 1758)

Nassariidae

Hebra horrida (Dunker, 1847)

Nassarius acuminatus (Marrat, 1880)

N. acuticostus (Montrouzier, 1864)

$N$. agapetus (Watson, 1882)

N. albescens (Dunker, 1846 )

N. arcularia (Linnaeus, 1758)

N. bimaculosus (Adams, 1852)

N. caelatus (Adams, 1852)

N. canaliculatus (Lamarck, 1822)

N. castus (Gould, 1850) $\mathrm{x}$
$\mathrm{x}$
$\mathrm{x}$
$\mathrm{X}$
$\mathrm{X}$
$\mathrm{X}$
$\mathrm{X}$
$\mathrm{x}$ 
Table 2 (continued)

\begin{tabular}{llll}
\hline $1937 / 38$ & & 2005 & \\
\cline { 3 - 4 } & $\begin{array}{l}\text { Jakarta } \\
\text { Bay }\end{array}$ & Jakarta & Kep. \\
Bay & Seribu
\end{tabular}

N. comptus (Adams, 1852)

N. concinnus (Powys, 1835)

$N$. coronatus (Bruguière, 1789)

N. crenulicostatus (Shuto, 1969)

N. distortus (Adams, 1852)

N. elegans (Kiener, 1834)

N. elegantissimus Shuto, 1969

N. globosus (Quoy \& Gaimard, 1833)

N. gruneri (Dunker, 1846)

N. javanus (Schepman, 1891)

N. leptospirus (Adams, 1852)

N. limnaeiformis (Dunker, 1847)

N. livescens (Philippi, 1849)

N. luridus (Gould, 1850)

N. margaritifer (Dunker, 1847)

N. micans (Adams, 1852)

N. nodifer (Powys, 1835)

N. paupera (Gould, 1850)

N. pauperus (Gould, 1850)

N. pullus (Linnaeus, 1758)

N. semisulcatus (Rousseau, 1854)

N. silvardi Kool \& Dekker, 2005

N. sinusigerus (Adams, 1852)

N. siquijorensis (Adams, 1852)

N. stolatus (Gmelin, 1791)

N. sufflatus (Gould, 1860)

N. venustus (Dunker,1847)

N. vittatus (Adams, 1853)

N. spec. 1

N. spec. 2

N. spec. 3

N. spec. 4

Pectinidae

Amusium pleuronectes (Linnaeus, 1758)

Annachlamys striatula (Linnaeus, 1758)

Bractechlamys nodulifera (Sowerby, 1842)

Complicachlamys wardiana Iredale, 1939

Coralichlamys madreporarum (Sowerby, 1842)

Cryptopecten nux (Reeve, 1853)

Decatopecten radula (Linnaeus, 1758)

Excellichlamys histrionica (Gmelin, 1791)

Glorichlamys quadrilirata (Lischke, 1870)

Gloripallium pallium (Linnaeus, 1758)

Haumea minuta (Linnaeus, 1758)

H. rehderi (Grau, 1960)

Laevichlamys cuneata (Reeve, 1853)

L. lemniscata (Reeve, 1853)

L. limatula (Reeve, 1853)

L. squamosa (Gmelin, 1791)

Mimachlamys albolineata (Sowerby, 1842)

M. cloacata (Reeve, 1853)

Minnivola pyxidata (Von Born, 1778)

Pedum spondyloideum (Gmelin, 1791)

Semipallium flavicans (Linnaeus, 1758)

S. fulvicostatum (Adams \& Reeve, 1850)

Serratovola rubicunda (Récluz, 1843)

Volachlamys singaporina (Sowerby, 1842)

Veneridae

Anomalocardia squamosa (Linnaeus, 1758)

Antigona chemnitzii (Hanley, 1844)

Callista erycina (Linnaeus, 1758)

C. impar (Lamarck, 1818)

Circe sulcata Gray, 1838

Clementia papyracea (Gray, 1825)

Dosinia amphidesmoides (Reeve, 1850)

D. histrio (Gmelin, 1791)

D. prostrata (Linnaeus, 1758)

D. tumida (Gray, 1838)

Gafrarium dispar (Holten, 1802)

G. divaricatum (Gmelin, 1791)

G. melvilli (Lynge, 1990)

G. pectinatum (Linnaeus, 1758)

G. tumidum Röding, 1798
Table 2 (continued)

\begin{tabular}{|c|c|c|c|}
\hline & $1937 / 38$ & 2005 & \\
\hline & $\begin{array}{l}\text { Jakarta } \\
\text { Bay }\end{array}$ & $\begin{array}{l}\text { Jakarta } \\
\text { Bay }\end{array}$ & $\begin{array}{l}\text { Kep. } \\
\text { Seribu }\end{array}$ \\
\hline Globivenus embrithes (Melvill \& Standen, 1899) & & & $\mathrm{x}$ \\
\hline G. toreuma (Gould, 1850 ) & $\mathrm{x}$ & $\mathrm{x}$ & $\mathrm{x}$ \\
\hline Irus macrophyllus (Deshayes, 1854) & $\mathrm{x}$ & $\mathrm{x}$ & \\
\hline Lioconcha castrensis (Linnaeus, 1758) & $\mathrm{x}$ & & \\
\hline L. fastigiata (Sowerby, 1851) & $\mathrm{x}$ & & \\
\hline L. pseudofastigiata Lamprell \& Healy, 2002 & & $\mathrm{x}$ & $\mathrm{x}$ \\
\hline L. schioettei Lamprell \& Healy, 2002 & $\mathrm{x}$ & & \\
\hline Marcia hiantina (Lamarck, 1818) & $\mathrm{x}$ & $\mathrm{x}$ & \\
\hline M. opima (Gmelin, 1791) & $\mathrm{x}$ & & \\
\hline Meretrix casta (Gmelin, 1791) & $\mathrm{x}$ & & \\
\hline M. meretrix (Linnaeus, 1758) & $\mathrm{x}$ & & \\
\hline Paphia gallus (Gmelin, 1791) & $\mathrm{x}$ & & \\
\hline P. litarata (Philippi, 1848) & $\mathrm{x}$ & & \\
\hline P. undulata (Von Born, 1780) & $\mathrm{x}$ & & \\
\hline Periglypta crispata (Deshayes, 1854 ) & $\mathrm{x}$ & $\mathrm{x}^{*}$ & \\
\hline P. cf crispata & & $\mathrm{x}^{*}$ & \\
\hline P. lamellaris e/o lacerata (Schumacher, 1817) & $\mathrm{x}$ & $x^{*}$ & \\
\hline P. monilifera (Sowerby, 1853) & $\mathrm{x}$ & & \\
\hline P. puerpera (Linnaeus, 1771) & $\mathrm{x}$ & & $x^{*}$ \\
\hline P. reticulata (Linnaeus, 1758 ) & $\mathrm{x}$ & $x^{*}$ & $x^{*}$ \\
\hline P. spec. 1 & & $\mathrm{x}$ & $\mathrm{x}$ \\
\hline P. spec. 2 & & $x^{*}$ & \\
\hline Pitar albida (Gmelin, 1791) & $\mathrm{x}$ & & \\
\hline P. citrina (Lamarck, 1818) & $\mathrm{x}$ & & \\
\hline P. hebraea (Lamarck, 1818) & & & $\mathrm{x}$ \\
\hline P. intricata (Dautzenberg, 1907) & & & $\mathrm{x}$ \\
\hline P. limatula (Sowerby, 1853) & $\mathrm{x}$ & $\mathrm{x}$ & $\mathrm{x}$ \\
\hline P. manillae (Sowerby, 1851) & $\mathrm{x}$ & & \\
\hline P. marrowae Healy \& Lamprell, 1992 & & & $\mathrm{x}$ \\
\hline P. obliquata (Hanley, 1844) & $\mathrm{x}$ & & \\
\hline P. striata (Gray, 1838) & $\mathrm{x}$ & & \\
\hline$P$. spec. 1 & $\mathrm{x}$ & & \\
\hline P. spec. 2 & $\mathrm{x}$ & & \\
\hline Placamen calophylla (Philippi, 1836) & $\mathrm{x}$ & & \\
\hline Ruditapes variegatus (Sowerby, 1852) & $\mathrm{x}$ & $\mathrm{x}$ & \\
\hline Samarangia quadrangularis (Adams \& Reeve, 1850) & & & $\mathrm{x}$ \\
\hline Sunetta contempta Smith, 1891 & $\mathrm{x}$ & & \\
\hline S. scripta (Linnaeus, 1758) & $\mathrm{x}$ & & \\
\hline S. spec. 1 & $\mathrm{x}$ & & \\
\hline S. spec. 2 & $\mathrm{x}$ & & \\
\hline Tapes dorsatus (Lamarck, 1818) & & $\mathrm{x}$ & \\
\hline T. litteratus (Linnaeus, 1758) & $\mathrm{x}$ & $\mathrm{x}$ & $\mathrm{x}$ \\
\hline T. platyptycha (Pilsbry, 1901) & $\mathrm{x}$ & $\mathrm{x}$ & $\mathrm{x}$ \\
\hline T. variegatus (Sowerby, 1852) & $\mathrm{x}$ & $x^{*}$ & \\
\hline Timoclea marica (Linnaeus, 1758) & $\mathrm{x}$ & & $\mathrm{x}$ \\
\hline T. scabra (Hanley, 1845) & & & $\mathrm{x}$ \\
\hline T. scandularis (Hedley, 1909) & $\mathrm{x}$ & & \\
\hline T. subnodulosa (Hanley, 1844) & & & $\mathrm{x}$ \\
\hline
\end{tabular}

Collected as beach material.

collections (Table 1 ). Over a total of 70 genera, 16 genera $(\sim 23 \%)$ disappeared and one genus (Laevicardium) was recorded as new for the bay area. With inclusion of the Kepulauan Seribu, nine new genera $(\sim 13 \%)$ were recorded in 2005 .

\section{Discussion}

The faunal deterioration of Jakarta Bay's reefs is reflected by the overall decline in species diversity, but also involved shifts in the faunal composition. There are scenarios for the deterioration of the fauna of Jakarta Bay, which includes environmental factors such as bleaching resulting from the 1982/83 ENSO event (Brown and Suharsono, 1990; Hoeksema, 1991), and anthropogenic factors such as land-based contaminants, man-made objects, oil pollution, domestic and industrial refuse (Sutamihardja, 1985; Willoughby, 1986; Uneputty and Evans, 1997; Rees et al., 1999). Some molluscan families are especially valued for the aquarium and shell collecting trade, perhaps further impacting their faunal composition. However, there is no specific reference available indicating the im- 
pact of commercial shell trade (Dharma, 2005). In the Jakarta Bay reef degradation diminishes toward the Thousand Islands archipelago, speculated to be the result of diminishing human impact and pollution (Moll and Suharsono, 1986; Verstappen, 1988; Cleary et al., 2006). Already in 1927 the reefs surrounding Onrust Isl. were excluded from reef studies, due to measurable anthropogenic influences (Zaneveld and Verstappen, 1952; Verstappen, 1953). Since then, the environmental pressure on Jakarta Bay increased and has been noted in several studies (e.g. Brown, 1986; Ongkosongo, 1989; Tomascik et al., 1993).

Between 1937/38 and 2005, the molluscan fauna of Jakarta Bay exhibited a change in species composition and decline in species richness. The number of species present in Jakarta Bay decreased from 171 to 58 (Fig. 2). The six mollusc families showed a strong decline in number of species, ranging from $51 \%$ (Veneridae) to 85\% (Nassariidae). Moreover, 16 genera were no longer found in Jakarta Bay after 1937/38 (Table 1). The increased environmental stress has influenced the coral reefs in the area, with which the molluscs are associated.

The molluscan families all represent different (aut-)ecological signatures, and have a different (economic) values for Jakarta's population. The venerid bivalves were the least affected in species numbers, although their edibility probably influenced the observed faunal composition change. Cardiid bivalves and pectinids are filter feeding taxa, likely able to better withstand the sediment stress in the area. Cypraeid snails, herbivorous grazers, have declined in numbers by approximately 53\%. Like conid snails, cypraeids are associated with (semi-)consolidated sea bottoms, including reef rubble and coral stands. Nassariid snails live primarily in sand, which makes sampling more difficult. Conid and nassariid snails probably also suffered from the decline in prey. It is unclear why the reefs at the outer side of Jakarta Bay (Fig. 2) show a greater loss in diversity than the near-shore islands. A possible explanation for the higher species richness of some of the near-shore islands is the higher primary production in more severely polluted areas that might offer increased opportunity for herbivory.

When factoring the 2005 faunal composition of the Kepulauan Seribu, similarities in species numbers to the $1937 / 38$ fauna of Jakarta Bay become apparent (Fig. 3). This is especially true for the Cardiidae and Conidae, and somewhat less for the Pectinidae. The Veneridae show a remarkable decline in species number, possibly as a result of shellfish exploration. It appears that Jakarta Bay in $1937 / 38$ shared various characteristics with Kepulauan Seribu in 2005, such as more carbonate substrate (higher coral cover) and less sedimentation. Nevertheless, the faunal compositions of 1937/38 in Jakarta Bay and of 2005 in Kepulauan Seribu show remarkable differences (Table 2 ), which are most likely related to different ecological circumstances.

The data collected over a 70-year time span in Jakarta Bay does not allow for rigorous statistical analyses. However, the value of this historical dataset is compelling in a temporal sense. While different collectors and collecting methods have influenced the data presented in this article, the data strongly supports an overall decrease in molluscan species diversity. The observed decline in species numbers and shifts in species composition are indisputable. The Jakarta Bay molluscan fauna has shifted from a previous high biodiversity area to a lower biodiversity value. Patterns in faunal composition and degradation of the reefs are unmistakably present. Ongoing urbanization of the coastal areas is expected and recovery of the molluscan fauna (associated with the coral reefs) is unlikely.

\section{Acknowledgements}

This publication is a result of the Kepulauan Seribu Expedition, September 2005, organized by the Research Centre for Oceanogra- phy, Indonesian Institute of Sciences (PPO-LIPI, Jakarta, Indonesia) and Naturalis. We are grateful to LIPI for granting research permits. The research was partly funded through ALW-NWO grant 852.000.50, within the research theme "Biodiversity in relation to global change" of the Netherlands Organisation for Scientific Research. The first author received a Mia J. Tegner Memorial Research Grant in Marine Environmental History and Historical Marine Ecology (Marine Conservation Biology Institute), to elaborate and complete the present study. The A.M. Buitendijkfonds (Naturalis) and Leiden University funds funded the first author's participation in the expedition.

Taxonomic assistance has been given by Mr. H.H. Dijkstra (Pectinidae), Mr. H. Kool (Nassariidae), Mr. P.L. van Pel (Cypraeidae), and Mr. J.J. ter Poorten (Cardiidae) from ZMA. The Veneridae were identified by the first and second author, the Conidae were identified by the second author. Mr. J.J. ter Poorten provided background information on the Cardiidae. Mr. J. Goud (Naturalis) collected beach material during the 2005 expedition. Dr. F.P. Wesselingh, Mr. A.N. van der Bijl and Dr. J.D. Thomas critically read a previous version of the manuscript and made valuable comments.

\section{References}

Bell, P.R.F., Tomascik, T., 1993. The demise of the fringing coral reefs of Barbados and in regions in the Great Barrier Reef (GBR) lagoon - impacts of eutrophication In: Ginsburg, R. (Ed.), Proceedings of the Colloquium on Global Aspects of Coral Reefs: Health, Hazards and History. Rosenstiel School of Marine and Atmospheric Science, University of Miami, pp. 319-325.

Brown, B.E., (Ed.), 1986. Human induced damage to coral reefs, results of a regional UNESCO (COMAR) workshop with advanced training, Diponegoro University, Jepara, and National Institute of Oceanology, Jakarta, Indonesia, May 1985. UNESCO Report in Marine Science (40), UNESCO, Paris, pp. i-iv, 1-179.

Brown, B.E., Suharsono, 1990. Damage and recovery of coral reefs affected by El Niño related seawater warming in the Thousand Islands, Indonesia. Coral reefs $8,163-170$

Cleary, D.F.R., Suharsono, Hoeksema, B.W., 2006. Coral diversity across a disturbance gradient in the Pulau Seribu reef complex off Jakarta, Indonesia. Biodiversity and Conservation 15, 3653-3674.

Connell, J.H., 1997. Disturbance and recovery of coral assemblages. Coral Reefs 16, S101-S113.

DeVantier, L., Suharsono, Budiyanto, A., Tuti, Y., Imanto, P., Ledesma, R. 1998 Status of coral communities of Pulau Seribu (Indonesia). In: Soemodihardjo S. (Ed.), Contending with Global Change 10. Proceedings: Coral Reef Evaluation Workshop, Pulau Seribu, Jakarta, Indonesia, 1995. UNESCO, Jakarta, pp. 1-24.

Dharma, B., 2005. Recent and Fossil Indonesian shells. Hackenheim, Germany. 424pp.

Ginsburg, R., (Ed.), 1993. In: Proceedings of the colloquium on global aspects of coral reefs: Health, hazards and history. Rosenstiel School of Marine and Atmospheric Science, University of Miami, 420pp.

Hoeksema, B.W., 1991. Control of bleaching in mushroom coral populations (Scleractinia: Fungiidae) in the Java Sea: stress tolerance and interference by life history strategy. Marine Ecology Progress Series 74, 225-237.

Hughes, T.P., Connell, J.H., 1999. Multiple stressors on coral reefs: a long-term perspective. Limnology and Oceanography 44 (3:2), 932-940.

Hunter, C.L., Evans, C.W., 1993. Reefs in Kaneohe Bay, Hawaii: two centuries of western influence and two decades of data. In: Ginsburg, R., (Ed.), Proceedings of the Colloquium on Global Aspects of Coral Reefs: Health, hazards and History. Rosenstiel School of Marine and Atmospheric Science, University of Miami, pp. 339-345.

Marques, J.C., Pardal, M.Â., Nielsen, S.N., Jørgensen, S.E., 1997. Analysis of the properties of energy and biodiversity along an estuarine gradient of eutrophication. Ecological Modelling 102, 155-167.

Moll, H., Suharsono, 1986. Distribution, diversity and abundance of reef corals in Jakarta Bay and Kepulauan Seribu. In: Brown, B.E. (Ed.), Human Induced Damage to Coral Reefs, Results of a Regional UNESCO (COMAR) Workshop with Advanced Training, Diponegoro University, Jepara, and National Institute of Oceanology, Jakarta, Indonesia, May 1985. UNESCO Reports in Marine Science, vol. 40 , pp. $112-125$.

Ongkosongo, O.S.R., 1989. Background Information for the Field Trip to the Seribu Reefs, Indonesia - Short Course on Carbonate Sedimentology and Stratigraphy. Jakarta 4-8 September 1989. Indonesian Petroleum Association, 270pp.

Poorten, J.J. ter, 2007. Results of the Rumphius Biohistorical Expedition to Ambon (1990). Part 13. Mollusca, Bivalvia, Cardiidae. Zoologische Mededelingen 81 (I), 259-301.

Rees, J.G., Setiapermana, D., Sharp, V.A., Weeks, J.M., Williams, T.M., 1999 Evaluation of the impacts of land-based contaminants on the benthic faunas of Jakarta Bay, Indonesia. Oceanologica Acta 22 (6), 627-640. 
Renema, W., 2008. Habitat selective factors influencing the distribution of larger benthic foraminiferal assemblages over the Kepulauan Seribu. Marine Micropaleontology 68, 286-298.

Sutamihardja, R.T.M., 1985. Water quality in the coastal area: the Jakarta Bay experience. In: Katō, I., Kumamoto, N., Matthews, W.H., Suhaimi, A. (Eds.), Environmental Protection and Coastal Zone Management in Asia and the Pacific. University of Tokyo Press, pp. 37-48.

Tomascik, T., Suharsono, Mah, A.J., 1993. Case histories: A historical perspective of the natural and anthropogenic impacts in the Indonesian archipelago with a focus on Kepulauan Seribu, Java Sea. In: Ginsburg, R. (Ed.), Proceedings of the Colloquium on Global Aspects of Coral Reefs: Health, Hazards and History. Rosenstiel School of Marine and Atmospheric Science, University of Miami, pp. 304-310.

Umbgrove, J.H.F., 1929. De Koraalriffen der Duizend-Eilanden (Java Zee). Wetenschappelijke Mededeelingen no. 12. Dienst van den mijnbouw in Nederlandsch-Indië, 1-47.

Umbgrove, J.H.F., Verwey, J., 1929. The coral reefs in the Bay of Batavia. Fourth Pacific Science Congress Java 1929, 30pp.
Uneputty, P.A., Evans, S.M., 1997. Accumulation of beach litter on Islands of the Kepulauan Seribu Archipelago, Indonesia. Marine Pollution Bulletin 34 (8), 652655.

Verstappen, H.Th., 1953. Djakarta Bay - a geomorphological study on shoreline development, Ph.D. Thesis University of Utrecht, $101 \mathrm{pp}$.

Verstappen, H.Th., 1988. Old and new observations on coastal changes of Jakarta Bay: an example of trends in urban stress on coastal environments. Journal of Coastal Research 4 (4), 573-587.

Verwey, J., 1931. Coral reef studies II \& III. Treubia 13, 169-198.

Williams, T.M., Rees, J.G., Setiapermana, D., 2000. Metals and trace organic compounds in sediments and waters of Jakarta Bay and the Pulau Seribu Complex, Indonesia. Marine Pollution Bulletin 40 (3), 277-285.

Willoughby, N.G., 1986. Man-made litter on the shores of the Thousand Island Archipelago, Java. Marine Pollution Bulletin 17 (5), 224-228.

Zaneveld, J.S., Verstappen, H.Th., 1952. A recent investigation about the geomorphology and the flora of some coral islands in the Bay of Djakarta. Journal for Scientific Research 3, 58-68. 